NBER WORKING PAPER SERIES

\title{
THE EFFECTS OF LIVING WAGE LAWS: EVIDENCE FROM FAILED AND DERAILED LIVING WAGE CAMPAIGNS
}

\author{
Scott Adams \\ David Neumark \\ Working Paper 11342 \\ http://www.nber.org/papers/w11342
}

\author{
NATIONAL BUREAU OF ECONOMIC RESEARCH \\ 1050 Massachusetts Avenue \\ Cambridge, MA 02138 \\ May 2005
}

\begin{abstract}
Any opinions expressed in this paper are those of the authors alone and do not necessarily reflect any position of the Public Policy Institute of California. We thank Chris Jepsen, Lori Kletzer, Jan Brueckner, and anonymous referees for helpful comments. Neumark is also Research Associate at the NBER, Research Fellow at IZA, and Visiting Scholar at the Institute of Business and Economic Research at UC-Berkeley. The views expressed herein are those of the author(s) and do not necessarily reflect the views of the National Bureau of Economic Research.
\end{abstract}

(C)2005 by Scott Adams and David Neumark. All rights reserved. Short sections of text, not to exceed two paragraphs, may be quoted without explicit permission provided that full credit, including $(\odot)$ notice, is given to the source. 
The Effects of Living Wage Laws: Evidence from Failed and Derailed Living Wage Campaigns Scott Adams and David Neumark

NBER Working Paper No. 11342

May 2005

JEL No. J38, J58

\begin{abstract}
$\underline{\text { ABSTRACT }}$
Living wage campaigns have succeeded in about 100 jurisdictions in the United States but have also been unsuccessful in numerous cities. These unsuccessful campaigns provide a better control group or counterfactual for estimating the effects of living wage laws than the broader set of all cities without a law, and also permit the separate estimation of the effects of living wage laws and living wage campaigns. We find that living wage laws raise wages of low-wage workers but reduce employment among the least-skilled, especially when the laws cover business assistance recipients or are accompanied by similar laws in nearby cities.
\end{abstract}

Scott Adams

Department of Economics

University of Wisconsin - Milwaukee

Milwaukee, WI 53201

sjadams@uwm.edu

David Neumark

Public Policy Institute of California

500 Washington Street, Suite 800

San Francisco, CA 94111

and NBER

neumark@ppic.org 


\section{Introduction}

The number of cities, counties, and school districts with living wage ordinances across the United States has swelled to nearly 100 . Living wage laws have three central features. First, they impose a wage floor that is higher — and often much higher — than traditional federal and state minimum wages. Second, living wage levels are often explicitly pegged to the wage level needed for a family with one full-time, year-round worker to reach the federal poverty line. Typical living wage levels as of December 2002 (when our sample period ends) were \$8.17 (Los Angeles), \$9.05 (Detroit), and \$10.25 (Boston). Third, coverage by living wage ordinances is highly restricted. Frequently, cities impose wage floors only on companies under contract (generally including non-profits) with the city. Other cities also impose the wage floor on companies receiving business assistance from the city, in almost every case in addition to coverage of city contractors. Finally, a much smaller number of cities also require that municipal employees receive a legislated living wage. Previous estimates have found that living wage laws increase the wages of low-wage workers. On the flip side, however, there are negative employment effects on workers at the low end of the skill distribution (Neumark and Adams [1] and [2]; Adams and Neumark [3]).

In most cases, living wage laws were preceded by vigorous living wage campaigns. In fact, many cities in the United States that do not have living wage laws have experienced campaigns to try to get living wage legislation enacted. In some cities living wage campaigns took things quite far before ultimately failing or being derailed because of a court ruling, state legislative action, a negative city council vote, a mayoral veto, or even non-enforcement following enactment. Although living wage campaigns vary in magnitude and intensity, it typically takes a considerable effort for a living wage campaign to reach the point where it fails or is derailed for one of the reasons just given. In addition, the strongest campaigns often entail some degree of organization and mobilization among low-wage workers and their advocates, and heightened public discussion of the plight of low-wage workers. A prime example is provided by the case of the Los Angeles living wage movement, which overlapped with the 
"Justice for Janitors" campaign. ${ }^{1}$ Thus, the momentum for change that begins with a living wage movement might ultimately result in changes in wage setting norms and firm behavior, even if no legislation ultimately results. Wages might be increased in response to public pressure or the greater organizing of low-skill labor. This, however, may in turn lead to lower employment as individual employers respond to the higher wages.

Aside from this substantive interest in the impact of living wage campaigns, the cities that experience vigorous but unsuccessful living wage campaigns provide a potentially valuable source of information for obtaining more compelling estimates of the effects of living wage laws than we have obtained in our previous research. First, as is standard in the types of difference-in-differences estimation strategies that we have used, the control group for the statistical experiment involved in estimating the effects of living wage laws is the set of cities in which a living wage law has never passed. But this approach only reliably uncovers the causal effects of living wage laws if the ceteris paribus assumption holds - that is, if all else is equal in the treatment and control groups except for the passage of the living wage law. While this is likely to hold if living wage laws and campaigns arise randomly, and if living campaigns either have no independent effect or always succeed, neither of these conditions is likely to hold in practice. If living wages are passed in cities that are undergoing changes in outcomes for lowwage or low-skill workers-perhaps because cities endogenously choose to enact living wages based in part on these changes, or living wage campaigns arise in part in response to them-then the overall set of cities not passing living wage laws may not serve as an adequate control group. Second, if living wage campaigns generate some of their own effects, then it is only the experience of cities that enact (and enforce) living wage laws relative to the experiences of cities with failed or derailed living wage campaigns that reveal the effects of living wage laws that are independent of the effects of living wage campaigns.

\footnotetext{
${ }^{1}$ Luce [4] and Zabin and Martin [5] discuss the organizations and political activities surrounding other living wage campaigns.
} 
For both of these reasons, this paper pursues the strategy of using the narrower set of cities with failed or derailed living wage campaigns as the control group for estimating the effects of living wage laws. Clearly these cities are not identical to cities with living wages, because ultimately a living wage law was not enacted. But they seem likely to be far more similar in terms of whatever underlying changes may have been associated with a vigorous living wage campaign arising, in which case they provide a better counterfactual for estimating the independent effects of living wage laws. In addition, the cities with failed or derailed living wage campaigns can be used to obtain independent estimates of the effects of living wage campaigns per se, based on comparisons to cities with no campaigns.

Although this paper is specifically concerned with the effects of living wage laws, it also addresses the more general issue of the estimation of the effects of policy changes. In innumerable contexts, researchers estimating the effects of policy changes on outcomes have to grapple with questions of different underlying trends in jurisdictions where the policy changes were and were not enacted, or in periods before or after the policy change, which may confound estimation of the effects of the policy change. A few examples are the effects of affirmative action (Smith and Welch [6]), workers' compensation deregulation (Thomason et al. [7]), minimum wages (Burkhauser et al. [8]), and welfare reform (Bitler et al. [9]). But accounting for trend differences typically requires some form of functional form restriction—-such as different trends in the treatment and control group that are restricted to be linear. For example, in the context of panel data over time on geographic regions such as cities or states, and a single discrete policy change that "turns on" at some point during the sample period, we cannot include separate time dummy variables for the treatment and control groups, since these would be perfectly collinear with the policy change. An alternative approach is to identify a group that is unaffected by the policy change but reflects the same underlying trends as the affected group, leading to a difference-in-difference-in-differences estimator (Gruber [10]); but this approach often requires strong assumptions pertaining to the absence of an effect on the group introduced to provide a third level of differencing. In contrast, the approach taken in this paper uses variation induced by the policy change 
succeeding in some regions and nearly succeeding in other regions to obtain a better control group., ${ }^{2,3}$

There may, of course, be contexts in which such an approach is not available. But where it is available, it seems a potentially better way of estimating effects of policy changes, and, at a minimum, a way of assessing the robustness of results obtained using more conventional methods.

\section{Living Wage Laws, Previous Research, and Motivation for Using Failed or Derailed Campaigns as Controls}

Information on the living wage laws covering cities large enough for us to analyze reliably is reported in Table 1. Like minimum wages, the central goal of living wages is to raise incomes of lowwage workers so as to reduce poverty. Thus, in our view, the key research question with regard to living wages is whether they help low-wage workers and low-income families. This question has been at the core of our research on living wages (Neumark and Adams [1] and [2]; Adams and Neumark [3]), as well as other work following up on this research. ${ }^{4}$ Several findings emerged from these studies. First, among those in the lowest decile of their city's wage distribution, living wages appear to have a detectable effect on wages. Second, those in the lowest decile of their city's skill distribution are less likely to be employed after their city passes a living wage ordinance. Third, the net effect of these laws is to reduce poverty rates. Finally, some features of living wage laws and the cities that pass them seem to be of considerable consequence for the magnitude (and hence also the statistical significance) of the estimated effects. Specifically, the laws that cover firms receiving financial assistance from the city lead to larger and more statistically significant effects on low-wage and low-skill workers. In addition, legislation in cities where laws are also in effect in nearby jurisdictions leads to stronger effects. In contrast, cities

\footnotetext{
${ }^{2}$ The approach has some parallels to research by DiNardo and Lee [11] estimating the effects of unionization on establishment closure by comparing establishments in which union representation elections just succeeded to those where they just failed. Because DiNardo and Lee have measures of election results along a continuum, they can implement this as a regression discontinuity design. In our case, living wage campaigns fail for a variety of reasons and not always as a result of a vote, so these methods cannot be implemented formally.

${ }^{3}$ Note that we can still allow for different linear trends (or some other functional form) in the treatment and the alternative control group, as we do in this paper, but this problem should be less important, because the underlying changes should be more similar in the two groups.

${ }^{4}$ For a general overview, see Lundberg et al. [12].
} 
where laws only cover contractors and where their law is the only one in the vicinity do not experience significant effects from living wage legislation (Adams and Neumark [13]).

In our other work we have suggested that the larger effects of business assistance living wage laws may arise because of extended coverage, and because there are fewer avenues for mitigating the costs (and therefore the effects) of living wage laws for employers covered under business assistance provisions. For example, contractor-only laws typically require that employers pay the mandated wage only for work done as part of the contract, allowing employers to mitigate the costs of complying with living wage laws by reallocating their higher-wage labor to the contract work and their lower wage labor to the non-contract work, and even reducing wages on non-contract work; in contrast, an establishment created with the help of business assistance from a city would appear to have no choice but to pay all employees no less than the mandated living wage for all of their work. Similarly, laws in nearby jurisdictions may amplify the effects of any city's living wage law. For example, consider an employer who has business with multiple cities. If a small share of the business is covered by a living wage law, because only one of the cities with which the employer has contracts is covered, then there will be more scope for mitigating the effects of a living wage law. But if nearby cities have living wage laws, more of the employer's work is likely to be covered by such laws and therefore the employer would have less scope for reducing wages on other work done by its employees, and also less scope for shifting business away from the city that imposes the living wage law. ${ }^{5}$

One striking feature of our findings, though, is the large magnitudes of the effects of living wage laws that we find. For example, in our first paper estimating living wage effects (Neumark and Adams [1]), for the bottom decile of the wage distribution the estimated wage effects of living wage laws overall yield an elasticity of wages with respect to the living wage of approximately $0.05-0.07$. This estimate is much larger than would be expected based on the apparently limited coverage of workers by most living wage laws. For example, as noted in Neumark and Adams [1], an upper bound for the fraction of workers

\footnotetext{
${ }^{5}$ Another potential reason for stronger effects of laws in nearby cities is that our data geographically identify respondents by place of residence rather than place of work. If laws exist in two municipalities, it increases the chances that a resident in either city will be covered by a living wage law.
} 
in the lower decile of the wage distribution that is covered by the contractor provisions of living wage laws is 0.025 . Since we would expect a maximum wage elasticity of one for affected workers, the largest effects we should expect are approximately equal to the proportion of workers who are likely to be affected by the living wage, giving us an upper bound elasticity of wages in this decile with respect to the living wage of 0.025 (and an expected elasticity that is likely much lower), in contrast to the figures just cited. A similar argument could be made regarding the magnitudes of the employment effects that we find.

One potential explanation of these large effects is that the apparent effects of living wage laws that we find may reflect not only the impact of these laws, but also the effects of campaigns resulting from organizing low-wage workers, public debate, etc. That is, the momentum for change that begins with a living wage movement might ultimately result in changes in wage setting norms and firm behavior (and also lower employment as individual employers respond to the higher wages), independent of the legislation. In contrast, the direct effects of living wage laws may be more modest.

Our analysis in this paper using cities with failed or derailed living wage campaigns to construct counterfactuals for successful living wage laws helps to assess this argument. If living wage movements are accompanied by increased organizing of low-wage workers and increased focus of public debate on the problems of workers at the bottom of the wage distribution, then including many cities without a strong movement in the control group may overstate the direct effects of the legislation. By narrowing our control group to those cities with living wage campaigns, we remove from the control group those cities that experienced neither a living wage law nor a living wage campaign, and hence can avoid confounding the effects of living wage laws and living wage campaigns. This approach is explained in more detail in the next section, where we also discuss more general motivations for exploiting the information provided by failed or derailed living wage campaigns.

Information on proposed living wage ordinances that failed or were derailed is summarized in Table 2. The reasons for failure vary. State legislation in Louisiana and Utah explicitly prevented living wage ordinances from being enforced in Baton Rouge, New Orleans, Provo, and Salt Lake City. In St. 
Louis, a law was passed but ultimately never enforced due a judicial decision. These five cities together may represent a better control group, as campaigns were halted by an outside legislative or judicial body, rather than a failure at the city level. Another advantage of this narrower control group is that there is a clear end of the campaign in these cities, as it is unlikely that a major campaign would resume amidst the judicial or legislative opposition, and indeed none appears to have resumed. Therefore, we can look at wages and employment before the law was passed and after it was nullified, which presents a clear counterfactual to those cities that pass legislation. On the other hand, in only two of these five cities-New Orleans and St. Louis-were the laws passed at the city level prior to being nullified, raising the possibility that the other three cities were less similar to cities where living wages passed than were cities where a campaign almost succeeded at the city level. In addition, this control group is limited because it contains only five cities, and the campaigns in these five cities ended in a relatively narrow time span (2001-2002). The five campaigns, labeled group A in Table 2, will be referred to as derailed campaigns throughout the paper.

Another group of cities had campaigns that progressed to the point where a decision was reached at the city level, but no legislation was ultimately enacted. Some reached a vote in city council and failed. Some fell victim to a mayoral veto. The ultimate failure of these campaigns to result in legislation suggests that they might have been weaker campaigns, but they still typically entailed increases in lowwage organizing and community activity, paralleling cities in which living wage laws passed. ${ }^{6}$ Thus, along with the cities in group A in Table 2, whose campaigns were derailed, these cities with campaigns that failed at the city-level may also be candidates for a reliable control group, and may be necessary because the set of derailed living wage campaigns is so small. This second set of potential control cities, labeled group B in Table 2, will be referred to as failed campaigns throughout the paper.

By employing control groups in which the "background" effects of living wage campaigns are better held constant, the true effects of provisions of the laws actually implemented can be more reliably

\footnotetext{
${ }^{6}$ Note that the vast majority of living wage campaigns never get as far as one of the outcomes classified as failure in Table 2. For example, in California, there are about 20 jurisdictions in which living wages have passed, and nearly as many in which campaigns arose but did not get to the point of a formal vote on a proposal or ballot initiative.
} 
identified. In the process, we can also speak to the question of whether campaigns to pass living wage laws have any detectable effects on wages and employment on their own, apart from any legislation that may result.

\section{Data and Methods}

\subsection{Data}

To conduct this analysis, we require information on living wage laws, living wage campaigns, and labor market outcomes for workers in cities both in a period before laws were passed (or failed or were derailed) and after. The information on living wage laws and campaigns that we use was already reported in Tables 1 and 2. The data on labor market outcomes and other worker-related characteristics come from the CPS monthly Outgoing Rotation Group files (ORGs) extending from January 1996 through December 2002. ${ }^{7}$ Because cities cannot be identified in the ORG files for a period in 1995, coupled with the fact that most living wage laws came into effect in 1996 or after, we restrict the sample to begin in $1996 .^{8}$ In these files, residents of all MSAs, encompassing all large- and medium-sized cities in the United States, can be identified.

The CPS has some disadvantages and some advantages for studying the effects of living wages and their accompanying living wage campaigns. First, the correspondence between cities and MSAs is imperfect. However, because covered employers may employ workers who do not live in the city, we do not necessarily want to restrict attention to city residents. Moreover, the CPS identifies where workers live, rather than where they work, and many suburban residents work in the city. However, if living wage laws affect city residents most strongly, our estimates might understate somewhat the impact of living

\footnotetext{
${ }^{7}$ The CPS is a stratified random sample based on sampling units within strata. However, the sampling units made up of the most populous areas (including large- and medium-sized metropolitan areas) are in strata by themselves, so that these areas are always sampled, and, by design, sampling units are self-representing. That is, the sampling unit covering an MSA is intended to be representative of the population of that MSA, not that MSA plus other sampling units in the strata. Finally, the households sampled within each sampling unit are chosen to be representative of the demographic and socioeconomic characteristics of the sampling unit. As a result, we can use the CPS to construct representative wage and skill distributions for the MSAs. In a small number of cases, though, outlying counties are excluded from the CPS sampling frame for an MSA, in which case the data are representative of the remainder of the MSA. (See U.S. Bureau of Labor Statistics [14]; U.S. Bureau of the Census [15])

${ }^{8}$ Specifically, for part of 1995 MSA codes are unavailable in the ORGs due to phasing in of a new CPS sample based on the 1990 Census.
} 
wage laws on city residents. On the other hand, there are numerous small cities within MSAs that have living wage laws paralleling those in the main cities in the MSA. ${ }^{9,10}$

A related concern is that the CPS contains virtually no information on one's employer.

Therefore, it is not possible to identify covered and uncovered workers. Instead, all we can identify is the MSA in which a worker lives and the type of law prevailing there. Obviously, CPS data are not useful in exploring the microeconomic effects of living wages at the firm or establishment level-i.e., questions such as whether firms engage in substitution away from low-wage labor, how much wages are increased for their lowest-wage workers, how employment responds, whether turnover falls, etc. ${ }^{11}$ On the other hand, the CPS data are very useful (and perhaps the best data available at present) for addressing policy questions regarding the effects of living wages on low-wage workers, because they permit us to estimate the net effects (including indirect or perhaps "general equilibrium" effects) of living wage laws on workers in the cities where they are passed, relative to other cities. The goal of this paper is to explore the interpretation and validity of evidence of such net effects on wages and employment in cities enacting living wage laws.

\subsection{Basic Methods}

We first discuss the basic approach that follows our earlier work, and then go on to explain the added information we can get from exploiting cities with failed and derailed living wage campaigns, and how we use the data to do so. To study wage effects, our basic approach uses a standard difference-indifferences approach to estimate the effects of living wage laws on workers in the bottom $10^{\text {th }}$ of each

\footnotetext{
${ }^{9}$ See http://www.epiononline.org/lw_proposal_map.cfm. Note that Table 1 does not list living wages in smaller cities. For expositional ease, from this point on we often refer to cities rather than MSAs.

${ }^{10}$ As this discussion highlights, there is clearly an important challenge for empirical research on living wages to try to better isolate effects on covered workers. However, we believe that the distinction between workers employed by firms that are or are not covered, discussed next, is by far the most important distinction.

${ }^{11}$ Such questions are best addressed using direct survey data on covered employers (and ideally a control group of uncovered or unaffected employers), as has begun to occur in some recent research (e.g., Brenner [16] and Fairris [17]).
} 
city's wage distribution in each month. ${ }^{12}$ Pooling data across months, we estimate the following regression

$$
\begin{aligned}
\ln \left(\mathrm{w}_{\mathrm{ijst}}^{\mathrm{p}}\right) & =\alpha+\mathrm{X}_{\mathrm{ijst}} \omega+\beta \cdot \ln \left(\mathrm{w}^{\min }{ }_{j s t^{\prime}}\right)+\gamma \cdot \max \left[\ln \left(\mathrm{w}^{\mathrm{liv}}{ }_{j \mathrm{t}}\right), \ln \left(\mathrm{w}^{\min }{ }_{j s t^{\prime}}\right)\right] \\
& +\delta_{\mathrm{Y}} \mathrm{Y}_{\mathrm{t}}+\delta_{\mathrm{M}} \mathrm{M}_{\mathrm{s}}+\delta_{\mathrm{C}} \mathrm{C}_{\mathrm{j}}+\theta \cdot \mathrm{T}+\theta_{\mathrm{LW}} \cdot \mathrm{T} \cdot \mathrm{LW}_{\mathrm{js}}+\varepsilon_{\mathrm{ijst}}
\end{aligned}
$$

This specification requires some explanation. $\mathrm{w}^{\mathrm{p}}$ is the hourly wage for individuals below the $10^{\text {th }}$ centile of the wage distribution. ${ }^{13}$ The subscripts ' $i$ ', ' $j$ ', 's', and ' $t$ ' denote individual, city, month, and year. $\varepsilon$ is a random error term. $\mathrm{X}$ is a vector of individual characteristics (age, sex, race, education, and marital status), $\mathrm{w}^{\mathrm{min}}$ is the higher of the federal or state minimum wage, ${ }^{14}$ and $\mathrm{w}^{\text {liv }}$ is the higher of the living wage or the minimum wage. $\mathrm{Y}, \mathrm{M}$, and $\mathrm{C}$ are vectors of year, month, and city (MSA) dummy variables. $\mathrm{T}$ is linear time trend; by interacting it with a time-invariant variable $\mathrm{LW}$ indicating whether a city ever imposes a living wage law in the sample period, we allow cities with and without living wage laws to have different time trends, as discussed in more detail below. ${ }^{15}$ When cities have very few observations for a given month, determining whether a worker falls in the bottom $10^{\text {th }}$ of the distribution is unreliable. We therefore restrict our sample for each analysis to city-month cells with at least 25 observations, although many have far more observations.

We always restrict attention to living wages (and minimum wages) at a lag of 12 months ( $\mathrm{t}^{\prime}$ ), because our past work has found that living wage effects become strong and statistically significant about

\footnotetext{
${ }^{12}$ For the estimation of wage effects, we restrict our sample to workers with an hourly wage greater than one dollar and less than or equal to 100 dollars. We also limit the sample to those between the ages of 16 and 70, inclusive. The latter restriction is also applied to the employment analysis.

${ }^{13}$ The regressions should therefore be interpreted as effects on a conditional mean rather than a population regression function, since our sample is limited to low-wage workers. However, we have verified in previous work that our approach is robust to specifications that do not truncate the sample. Specifically, our results were similar using a specification where city-months are the unit of analysis and the $10^{\text {th }}$ centile of the wage distribution in the city month is the dependent variable. Also, when we estimated a quantile regression on the entire wage distribution (appropriately leaving out the controls for worker characteristics in the $\mathrm{X}$ vector), the evidence was similar. See Adams and Neumark [3] for more details.

${ }^{14}$ In the few cases of MSAs that straddle states with different minimum wages in some years (Davenport-Quad Cities, Philadelphia, Portland, and Providence), we use a weighted average of the minimum wages in the two states, weighting by the shares of the MSA population in each state (averaged over the months of 1996).

${ }^{15} \mathrm{LW}$ is not included on its own (i.e., not interacted with $\mathrm{T}$ ) because it is captured in the city dummy variables. The time trend in the cities without a living wage law $(\mathrm{LW}=0)$ is actually more flexible, and is captured in the year and month dummy variables.
} 
a year after passage, and that little generality is lost by simply focusing on the 12-month lag. ${ }^{16}$ Living wage effects may arise with a lag because cities take some time to communicate and establish procedures for living wage compliance and enforcement (Sander and Lokey [18]). In addition, contracts only become subject to living wage provisions once they are renewed, although some effects of living wage laws can become operative prior to renewal of contracts.

The living wage variable that multiplies $\gamma$ is specified as the maximum of the (logs of the) living wage and the minimum wage. It is potentially important to control for minimum wages separately, because many cities with living wages are in states with high minimum wages, and we want to estimate the independent effects of living wages. The specification of the living wage effect imposes the minimum as the wage floor in the absence of a living wage. However, because living wages may have different effects from minimum wages, and because the effects of wage floors may differ in the narrower sectors to which living wages apply, the coefficient is allowed to differ from that of the standard minimum wage floor. If living wages boost the wages of low-wage workers, we would expect to find positive estimates of $\gamma$ when we are looking at workers at the low end of the wage distribution.

The year and month dummy variables control for common changes across cities in the sample that could otherwise be confounded with living wage effects, since living wages are typically enacted later in the sample period. The city dummy variables control for the possibility that living wage laws are passed in cities with either particularly high or low wages, which would again confound the estimation of their effects. Thus, this specification identifies an effect of the living wage when the dependent variable changes differentially in cities that pass living wage laws (or increase their living wage) relative to cities that do not pass living wage laws-a difference-in-differences research design.

The difference-in-differences strategy is predicated on the assumption that absent the living wage, and aside from differences captured in the other control variables, the treatment and control groups are comparable. Note, though, that explicit controls for local labor market conditions are not included. While local labor market conditions can surely matter, they are also potentially endogenous if, for

\footnotetext{
${ }^{16}$ The results are also not sensitive to using a contemporaneous minimum wage variable instead.
} 
example, living wages cause some job loss. Fixed differences in economic conditions between the treatment and control groups are captured in the city dummy variables, and the year and month dummy variables capture changes in economic conditions common to all cities. However, a potential problem arises if economic conditions are changing differentially by location. For this reason, to capture some dimensions of differing changes in economic conditions across cities, equation (1) also includes differential linear time trends for cities that do and do not pass living wage laws over the sample period. The difference in the trend for cities passing living wage laws is captured in the term $\theta_{\mathrm{LW}} \cdot \mathrm{T} \cdot \mathrm{LW}_{\mathrm{js}} \cdot{ }^{17} \mathrm{While}$ these trends do not capture every possible variation in local economic conditions, they capture systematic differences between the different groups of cities in the rates of change of wages and employment.

We use the same basic empirical framework to study employment, with only two differences. First, we estimate linear probability models for individual employment status. Second, whereas the wage analysis is done only for those employed and with a wage, the employment analysis is of course done for workers and non-workers. Because we cannot classify non-working individuals based on their position in the wage distribution, we instead impute wages for everyone and group individuals based on their position in the distribution of imputed wages, or "skills.","

Both the wage and employment specifications can be augmented to allow for differences in effects of living wage laws based on certain characteristics of the laws. We estimate these separate effects from specifications of the form

$$
\begin{aligned}
\ln \left(\mathrm{w}_{\mathrm{ijst}}^{\mathrm{p}}\right)= & \alpha+\mathrm{X}_{\mathrm{ijst}} \omega+\beta \cdot \ln \left(\mathrm{w}^{\mathrm{min}}{ }_{\mathrm{jst}}\right)+\gamma_{1} \cdot \max \left[\ln \left(\mathrm{w}^{\mathrm{liv}}{ }_{\mathrm{jst}}\right) \cdot \mathrm{L}_{1}, \ln \left(\mathrm{w}^{\min }{ }_{\mathrm{jst}}\right)\right] \\
& +\gamma_{2} \cdot \max \left[\ln \left(\mathrm{w}^{\mathrm{liv}}{ }_{\mathrm{jst}}{ }^{\prime}\right) \cdot \mathrm{L}_{2}, \ln \left(\mathrm{w}^{\mathrm{min}}{ }_{\mathrm{jst}}{ }^{\prime}\right)\right]+\delta_{\mathrm{Y}} \mathrm{Y}_{\mathrm{t}}+\delta_{\mathrm{M}} \mathrm{M}_{\mathrm{s}}+\delta_{\mathrm{C}} \mathrm{C}_{\mathrm{j}}+\theta \cdot \mathrm{T}
\end{aligned}
$$

\footnotetext{
${ }^{17} \mathrm{We}$ also experimented with allowing nonlinear trends by adding quadratic terms in $\mathrm{T}$, but the results were very similar to those we report. A referee suggested allowing for different trends before and after a living wage is passed. The suggestion amounts to asking whether there is an effect not only of the living wage, but of how many years the living wage has been in effect. This is something one might, in principle, be able to identify reliably with a very long time-series for each city, but not with the short time-series that we have available for each city.

${ }^{18}$ We do this in a simple manner, estimating a standard log wage regression with year and month controls, and using predicted log wages from the estimated regression to construct an imputed wage distribution for the MSA-month cell. Of course, the market wages faced by those who choose not to work may be lower than those faced by observationally-equivalent individuals who choose to work; this is the standard sample selection problem. We have verified that reducing the imputed wages of the non-workers by five percent and ten percent leads to results that are qualitatively similar.
} 


$$
+\theta_{1, \mathrm{LW}} \cdot \mathrm{T} \cdot \mathrm{LW}_{\mathrm{js}} \cdot \mathrm{L}_{1}+\theta_{2, \mathrm{LW}} \cdot \mathrm{T} \cdot \mathrm{LW}_{\mathrm{js}} \cdot \mathrm{L}_{2}+\varepsilon_{\mathrm{ijst}} \cdot
$$

What is different in this specification is the interactions with $\mathrm{L}_{1}$ and $\mathrm{L}_{2}$, which are dummy variables for the two different types of living wage laws under consideration. In this paper, we will consider two features of laws that will require this method of delineation. For some specifications, $\mathrm{L}_{1}$ will indicate laws with business assistance provisions and $\mathrm{L}_{2}$ will indicate laws that only cover contractors (as well as the couple of smaller cities that cover only municipal employees). For others, $\mathrm{L}_{1}$ will indicate laws passed where a nearby city also has a law while $\mathrm{L}_{2}$ will indicate laws passed where the city has the only law in the vicinity. As noted above, these two features of living wage legislation were found in previous studies to have a strong influence on whether living wage laws had a detectable effect (Adams and Neumark [13]). We now have two variables with the max of the logs of the living and minimum wages, interacting them with the dummy variables $\mathrm{L}_{1}$ and $\mathrm{L}_{2}$, respectively. The interaction occurs inside the max operator so that in the absence of a living wage the floor is the minimum wage, rather than zero. The parameters $\gamma_{1}$ and $\gamma_{2}$ then capture the differences in the effects of wage floors generated by living wages, allowing these to differ depending on the type of living wage law. In addition, we add separate interactions between the time trend, the indicator for a living wage law, and $\mathrm{L}_{1}$ and $\mathrm{L}_{2}$, which allow the cities with different types of living wage laws to have different underlying trends, for the reasons outlined above. $^{19}$

\subsection{Extending the Analysis to Failed and Derailed Living Wage Campaigns}

In this paper, we extend this approach to exploit additional information provided by failed and derailed living wage campaigns. There are two principal motivations for this extension. First, in the difference-in-differences strategy outlined above, the control group for the statistical experiment involved in estimating the effects of living wage laws is the set of cities in which a living wage law is never passed. Implicitly it might appear that the pre-living wage observations in cities that eventually pass living wage laws (in the sample period) also serve as controls. But the difference-in-differences strategy identifies the

\footnotetext{
${ }^{19}$ The $\mathrm{L}_{1}$ and $\mathrm{L}_{2}$ variables in the max operators should have ' $\mathrm{t}$ ' subscripts in the case of nearby cities having living wages, as this classification sometimes changes over time.
} 
living wage effect from the difference between changes in wages and employment in the living wage cities pre- and post-living wages, compared to changes over comparable periods in the cities that never pass living wages, so the non-living wage cities provide the control group for this second level of differencing. Of course, as explained above, in the statistical model the city dummy variables account for fixed differences in wage and employment levels across cities, and the differential trends account for different trends in the two sets of cities. But the latter feature of the models only "works" to the extent that these differential trends are present for the entire sample period, which in the living wage cities means both before and after a living wage law is passed. If living wages are passed in cities that are contemporaneously undergoing changes in outcomes for low-wage or low-skill workers-perhaps because cities endogenously choose to enact living wages, because living wage campaigns are in part generated in response to these changes, or because of the effects of campaigns-then the overall set of cities not passing living wage laws may not serve as an adequate control group.

What we would like, instead, is a control group of cities in which whatever changes may have coincided with the passage of living wage laws also occurred. A natural set of candidates for such a control group is the cities in which there was a living wage campaign, but it failed or was derailed for one of the reasons outlined earlier. Clearly these cities are not identical to the living wage cities, because ultimately a living wage law was not enacted. But they seem likely to be far more similar in terms of whatever underlying changes may have been associated with a living wage campaign arising. Below, we discuss some of the issues involved in implementing this empirically.

The second motivation arises because, as noted earlier, the evidence on wage and employment effects of living wage laws that we have found in our past research tends to suggest effects that are larger than expected, especially if one thinks in terms of coverage of city contractors, which is by all estimates quite narrow (see Neumark and Adams [1]). Part of the explanation may be that we are picking up more than just the direct effects of legislated living wage laws, and instead are also detecting the broader effects of the organizing of low-wage labor, public debate, and strengthening of community organizations that are spurred by living wage campaigns. Because of this, we are interested in comparing the effects of 
successful living wage campaigns to failed and derailed living wage campaigns, to see how much of the effects of living wage laws that are actually implemented are in fact independent effects of these laws, rather than effects of the campaigns that would arise regardless of whether the campaign succeeded. By comparing the failed and derailed campaigns to the more standard control group, we can ask what effects living wage campaigns, per se, have on low-wage or low-skill workers.

To answer these questions, we have to modify our approach in a couple of ways. First, and most simply, in estimating equations (1) and (2) we restrict the sample to cities that either successfully passed a living wage law or had a failed or derailed living wage campaign (groups A and B in Table 2). This approach uses the latter cities as the control group in the simplest possible way. We also conduct the analyses for a control group limited to just the group of cities with derailed campaigns (group A from Table 2). Although this removes from the analysis many of the cities in group B that had strong campaigns, it leaves us with a control group of cities in which campaigns only ended because of an outside decision by a legislative or judicial body, rather than—strictly speaking — a failed campaign. On the other hand, the group of cities with derailed campaigns includes only five cities in three states, and as noted earlier in three of the five cities a living wage law was pre-empted by the state legislature, so this group poses some limitations.

While we begin this analysis with a simple approach, better estimates can be obtained if we compare the changes in cities that successfully passed living wage laws with changes occurring in the cities with failed and derailed campaigns in an appropriate "before-and-after" period, rather than essentially averaging over changes in these control cities for the entire sample period. That is, we probably obtain the most reliable difference-in-differences estimates if we correctly align the before-andafter periods in the cities with successful campaigns with the counterfactual before-and-after period in the cities where campaigns failed or were derailed.

One challenge to implementing this approach is that we do not have a specific living wage level to assign to the cities in which the living wage campaign failed or was derailed. Therefore, as a preliminary step, we use versions of equations (1) and (2) in which we substitute a dummy for enactment 
of a living wage law for the continuous measure of the living wage. Letting DLW be a dummy variable equal to one when the living wage law is in effect, then equation (2), for example, becomes

$$
\begin{aligned}
\ln \left(\mathrm{w}_{\mathrm{ijst}}^{\mathrm{p}}\right)= & \alpha+\mathrm{X}_{\mathrm{ijst}} \omega+\beta \cdot \ln \left(\mathrm{w}_{\mathrm{jst}}^{\mathrm{min}}\right)+\gamma_{1} \cdot \mathrm{DLW}_{\mathrm{jst}} \cdot \mathrm{L}_{1} \\
& +\gamma_{2} \cdot \mathrm{DLW}_{\mathrm{jst}} \cdot \mathrm{L}_{2}+\delta_{\mathrm{Y}} \mathrm{Y}_{\mathrm{t}}+\delta_{\mathrm{M}} \mathrm{M}_{\mathrm{s}}+\delta_{\mathrm{C}} \mathrm{C}_{\mathrm{j}}+\theta \cdot \mathrm{T} \\
& +\theta_{1, \mathrm{LW}} \cdot \mathrm{T} \cdot \mathrm{LW}_{\mathrm{js}} \cdot \mathrm{L}_{1}+\theta_{2, \mathrm{LW}} \cdot \mathrm{T} \cdot \mathrm{LW}_{\mathrm{js}} \cdot \mathrm{L}_{2}+\varepsilon_{\mathrm{ijst}}
\end{aligned}
$$

with the obvious corresponding change in equation (1) that we do not spell out here. The main difference between equations (2) and (3) is in the interpretation of the estimates of $\gamma_{1}$ and $\gamma_{2}$. These parameters now capture the percentage changes in wages that result from the living wage laws on average, without regard to the actual level of the living wage. While this specification therefore discards information, it is the only way we are able to estimate comparable effects of actual living wage laws in the treatment group and corresponding "potential" living wage laws in the restricted control group of cities with failed or derailed living wage campaigns. We also report estimates of these specifications for the full sample, to provide a comparison with the results using the continuous living wage variable.

After verifying that moving to a dummy variable specification does nothing to substantively change the results, we move to the analysis that attempts to align the before-and-after periods in the cities with successful campaigns with the counterfactual before-and-after periods in the cities where campaigns failed or were derailed. To try to accomplish this, we take from an external source (see Table 2) the best estimate of the date the living wage campaign ended. There are unambiguous dates on which votes failed, laws were blocked, etc. For campaigns that failed at the city level due to a city council vote or mayoral veto, however, campaigns may restart, perhaps due to a change in the composition of city council or a change in mayor. Thus, our results that use information on the timing of living wage campaigns should be interpreted with this in mind. In contrast, for the cities in group A of Table 2 there is a clear end to these campaigns as a result of some exogenous decision by a judge or legislative body. As noted earlier, however, it only consists of five cities in three states. Thus, we still likely need to rely on the results using the larger control group of cities with either failed or derailed campaigns.

Then, given these dates, corresponding to the actual passage of a living wage law in the cities 
where a living wage law successfully passed we define the "treatment" of a failed or derailed living wage campaign as occurring at the ending date of the campaigns for these cities. It may seem odd to specify as the beginning of the treatment period the date at which the living wage campaign ended. But the presumption is that there was a living wage campaign in all of these cities-irrespective of whether the living wage law was ultimately enacted—so that there is no need to specify the "treatment" of the living wage campaign leading up to the final outcome. Instead, what we do by including a variable capturing the end of the living wage campaign is to simply "line up" the before-and-after observations in the subsample of cities with failed and derailed campaigns in the same way as the observations are lined up in the subsample of cities that pass living wage laws. The difference between the living wage "effect" in the two sets of cities is then the independent effect of the living wage laws.

We then proceed to the final step by augmenting the equation to let DLW instead be a dummy variable indicating that a living wage campaign has ended, and then interacting this variable with two indicators: $\mathrm{S}$ for successful campaigns, and $\mathrm{F}$ for failed or derailed campaigns, as in

$$
\begin{aligned}
\ln \left(\mathrm{w}_{\mathrm{ijst}}^{\mathrm{p}}\right)=\alpha & +\mathrm{X}_{\mathrm{ijst}} \omega+\beta \cdot \ln \left(\mathrm{w}_{\mathrm{jst}}^{\mathrm{min}}\right)+\gamma_{1} \cdot \mathrm{DLW}_{\mathrm{jst}} \cdot \mathrm{S}_{\mathrm{jst}} \cdot \mathrm{L}_{1}+\gamma_{2} \cdot \mathrm{DLW}_{\mathrm{jst}} \cdot \mathrm{S}_{\mathrm{jst}} \cdot \mathrm{L}_{2} \\
& +\gamma^{\prime} \cdot \mathrm{DLW}_{\mathrm{jst}} \cdot \mathrm{F}_{\mathrm{jst}}+\delta_{\mathrm{Y}} \mathrm{Y}_{\mathrm{t}}+\delta_{\mathrm{M}} \mathrm{M}_{\mathrm{s}}+\delta_{\mathrm{C}} \mathrm{C}_{\mathrm{j}}+\theta \cdot \mathrm{T}+\theta_{1, \mathrm{LW}} \cdot \mathrm{T} \cdot \mathrm{DLW}_{\mathrm{js}} \cdot \mathrm{S} \cdot \mathrm{L}_{1} \\
& +\theta_{2, \mathrm{LW}} \cdot \mathrm{T} \cdot \mathrm{DLW} \mathrm{Dss}_{\mathrm{js}} \cdot \mathrm{S} \cdot \mathrm{L}_{2}+\theta_{3} \cdot \mathrm{T} \cdot \mathrm{DLW}_{\mathrm{js}} \cdot \mathrm{F}+\varepsilon_{\mathrm{ijst}}
\end{aligned}
$$

The last three interaction terms now allow for different trends where there are successful or unsuccessful campaigns, and where campaigns are successful, trends are allowed to differ by the type of law that results. Again, there is an obvious version of this equation that corresponds to equation (1), not spelled out here. These specifications are estimated for the full sample. ${ }^{20}$

Returning to the main issues involved in developing this specification, $\left(\gamma_{1}-\gamma^{\prime}\right)$ and $\left(\gamma_{2}-\gamma^{\prime}\right)$ in equation (4) capture the effects of enacted living wages (of the two types captured by $\mathrm{L}_{1}$ and $\mathrm{L}_{2}$ ), relative to failed or derailed living wage campaigns. The parameters correspond to the difference-in-differences

\footnotetext{
${ }^{20}$ For the regression analyses where we focus only on the derailed campaigns (group A in Table 2), however, we drop cities from group B in Table 2 completely from the analysis, rather than including them in the broader control group.
} 
estimates of the effects of living wage laws using the failed and derailed living wage campaigns as the control group, which we suggest best identify the effects of living wage laws. What $\gamma^{\prime}$ captures is the "effect" of unsuccessful living wage campaigns, or how wages and employment in the cities with failed or derailed campaigns deviate from the group of cities with no living wage campaigns in the period after the campaign ends. For this latter analysis, the necessity of "dating" the failure or derailment of living wage campaigns is obvious.

\section{Empirical Results}

\subsection{Baseline Estimates}

In Table 3, we begin by presenting some of the basic results from our earlier research assessing the impact of living wage laws. In the top panel, we use the same control group we have used in our previous studies — cities that have not passed a living wage law during the sample period. This control group can include cities with strong movements that may result in living wage laws in the future, cities with weak movements, cities with movements that were derailed (group A in Table 2), cities with movements that failed at the city level (group B), and cities without any living wage activity at all.

The overall wage effects in column (1) suggest that living wage laws do have an impact on wages. The point estimate is 3.95, implying an elasticity of about 0.04 (given that the estimates in Table 3 are multiplied by 100). Although this estimate falls short of statistical significance, sharper statistical results emerge when we draw distinctions among different features of living wage laws. In particular, when we estimate separate effects for business assistance and contractor-only living wage laws, we find a significant impact only of business assistance laws. As shown in column (2), the estimated elasticity for business assistance laws is 0.07 , significant at the ten-percent level. Similarly, when we estimate separate effects for laws that are passed in a city with a neighboring city that also has a living wage law, the estimated elasticity is 0.09 and is significant at the five-percent level. As noted earlier, there are several reasons why one might suspect that these two features have the strongest impact. Business assistance provisions cover firms accepting financial assistance from the city and are normally passed in addition to provisions covering contractors, thus making it more likely that workers will be covered by these broader 
laws. Moreover, firms bound by business assistance provisions have less scope for mitigating the costs associated with the wage requirements. The same is true for laws passed in cities whose neighbors also have living wage laws, as neighboring living wage laws make it more difficult to shift business to areas not covered by a living wage law. ${ }^{21}$

The estimated employment effects of the living wage laws using the full control group appear in the top panel of columns (4)-(6). The estimated overall impact of living wage laws is given by the point estimate of -5.25 . This implies an employment elasticity of -0.12 , which is calculated by dividing the point estimate of the 5.25 percentage point reduction in employment for a one-unit increase in the log living wage (or a 100 percent increase) by the percentage of the bottom decile of the skill distribution that is employed (43.51). This employment estimate is statistically significant at the five-percent level. The effects are also stronger in those cities where the effects on wages were stronger-cities whose laws have business assistance provisions or with nearby cities that also have legislation—and weaker and statistically insignificant for the other cities. The employment results for business assistance laws and laws where nearby jurisdictions also have legislation imply elasticities of -0.17 and -0.23 , respectively. ${ }^{22}$

\subsection{Restricting the Control Group to Cities with Failed and Derailed Living Wage Campaigns}

We begin the analysis that exploits unsuccessful living wage campaigns in the middle panel of Table 3, restricting the control group for the difference-in-differences estimation to cities with failed or derailed living wage campaigns (both groups A and B from Table 2), and applying equations (1) and (2) to this restricted sample. What is notable from this approach is the similarity of the estimates to those in the first panel. The elasticity of wages with respect to living wages generally is near 0.04 and falls short of significance at conventional levels. The employment effect remains negative and statistically

\footnotetext{
${ }^{21}$ In Adams and Neumark [13], we show that these two features of living wage laws tend to coincide, and it is difficult empirically to determine whether one or the other is more important as an explanation of what underlies the stronger living wage effect.

${ }^{22}$ In Neumark and Adams [1], we estimated wage effects for the bottom decile of the skill distribution (imputed from individual characteristics) and presented similar findings to those presented in this paper, which use the bottom decile of the actual wage distribution. In Adams and Neumark [3], we examined whether there are any effects further up in the wage and skill distribution and found no significant effects. This is expected given that the wage floor does not directly affect these workers.
} 
significant at the five-percent level. When we separate the effect of the business assistance laws and the contractor-only laws, we also arrive at similar estimates to the top panel. The estimated wage effect for business assistance living wage laws declines only slightly, although combined with the higher standard error is no longer statistically significant at the ten-percent level. When we separate the effects of laws with nearby legislation and laws without nearby legislation, there is little change in the estimates, with an elasticity of 0.08 estimated for living wage laws when there are living wage laws in neighboring cities, and the estimated effect remains significant at the five-percent level. The employment effects are similar to those using the larger control group, whatever distinctions we draw among living wage laws. As with the overall effects, the effects for business assistance living wage laws and living wage laws accompanied by similar laws in neighboring cities remain statistically significant in the middle column when the control group is restricted to cities with failed or derailed campaigns. In the bottom panel of Table 3, we further restrict the control group to only those cities with derailed campaigns. There is virtually no change in either the wage or employment results. This suggests that it is the laws and not anything about the campaigns that generate the wage and employment effects that we observe.

\subsection{Refinements: Aligning Successful and Unsuccessful Living Wage Campaigns and Estimating the Effects of Campaigns}

As explained in Section 3, a limitation of the estimates in the bottom two panels of Table 3 is that they may not go far enough in using the subsample of cities with failed or derailed living wage campaigns as a control group. Instead, we next turn to the analysis using the estimated dates at which the living wage campaigns in the control cities failed or were derailed, to establish greater comparability with the enactment of living wages in the treatment cities.

To begin this analysis, in the top panel of Table 4 we examine the consequences solely of moving to the specification where we identify the effect of the living wage through the dummy variable DLW (from equation (3)) rather than the continuous measure of the living wage. The overall wage results, in column (1), are similar to the results using the continuous measure that appear in Table 3. The passage of a living wage, on average, increases wages of the bottom decile of the wage distribution by 1.68 percent 
when compared with all other cities, 1.52 percent when compared to set of cities with failed and derailed living wage campaigns, and 1.34 percent when compared only to the set of cities with derailed campaigns. The estimates in columns (2) and (3) again show that living wage effects on wages are sharper when there is a business assistance provision, or when a nearby city has a living wage law, with the estimated effects, as in Table 3, increasing by a factor somewhat less than two.

To compare these to the estimates in Table 3, it is useful to compute elasticities, which we can do by applying the estimated coefficients to the average living wage differential in the sample. This average is 60.5 percent overall, 66.7 percent for the business assistance living wage laws, and 66.3 percent for living wage laws accompanied by similar laws in nearby cities, implying wage elasticities of $0.03,0.05$, and 0.05 respectively when we use all other cities as the control group $(0.03,0.04$, and 0.04 using the more restrictive control group in the middle panel, and 0.02, 0.04, and 0.03 using the most restrictive control group in the bottom panel). Note, though, that these estimated wage effects tend not to be statistically significant, unlike in Table 3; this is a natural consequence of discarding the information on living wage levels.

The employment effects, on the other hand, are not only similar to the results in Table 3, but remain statistically significant. For example, when compared with all cities, a living wage law lowers the employment rate of the less-skilled by 2.34 percentage points, which implies an elasticity of about $-0.09 .^{23}$ The employment results using the alternative control group of cities with failed and derailed (or just derailed) living wage campaigns are similar. Separating the effects by those laws with and without business assistance provisions, as well as by whether a nearby city has a living wage law, again yields similar effects.

As with the wage effects, the estimated employment elasticities tend to be a little smaller (in absolute value) in Table 4. Aside from ignoring overall variation in the levels of living wages first implemented, the specifications used in Table 4 also ignore effects that result from subsequent increases

\footnotetext{
${ }^{23}$ The 2.34 percentage point decline in the employment rate represents a 5.4 percent decline in the 43.51 percent employment rate for this group, which is then scaled by the average 60.5 percent overall increase in the living wage.
} 
in living wages due to indexation to federal poverty guidelines or the CPI, which have been shown to have disproportionately larger effects in Neumark and Adams [1]. Even so, they are similar enough to suggest that we can use this approach in an acceptable way to estimate more finely the different impacts of successful and failed or derailed living wage campaigns.

Table 5 reports the results from estimating equation (4), and the corresponding equation that does not distinguish by type of living wage law. Specification 1 simply looks at the effects of successful and failed or derailed campaigns without distinguishing types of living wage laws, while specifications 2 and 3 draw the distinctions based on business assistance provisions and living wage laws in nearby cities, respectively. In column (1), the first row for each specification reports the estimated wage "effect" corresponding to failed or derailed campaigns, and the following rows report the corresponding parameters for successful campaigns; for specifications 2 and 3, referring back to equation (4), these are the parameters $\gamma^{\prime}$ (for unsuccessful campaigns) and $\gamma_{1}$ and $\gamma_{2}$ (for successful campaigns). Column (1') then reports the differences between these coefficient estimates-in the case of specifications 2 and 3 , the estimates of $\left(\gamma_{1}-\gamma^{\prime}\right)$ and $\left(\gamma_{2}-\gamma^{\prime}\right)$ — which provide the difference-in-differences estimates in which we are most interested. This analysis is also repeated using just derailed campaigns, and the results appear in columns (2) and (2'). Columns (3), (3'), (4), and (4') present the employment results in a similar fashion.

As noted earlier, we report all effects lagged by 12 months. For the effects of the living wage laws, there is a clear justification for looking at effects lagged by 12 months. For the unsuccessful campaigns, this is less obvious. A living wage campaign likely gains momentum as time goes on and perhaps continues to exert some influence after a law passes or fails. The point at which we would expect to begin to see an effect is uncertain. One of the questions in which we are most interested in, however, is whether the effects of living wage laws that we have detected reflect the effects of the laws themselves or just the effects of living wage campaigns. Thus, the most natural way to use the unsuccessful campaigns as a control group is to examine whether the time pattern of effects of living wage laws differs from those of living wage campaigns. As a consequence, for unsuccessful campaigns we use the same lag as for successful ones. 
The difference-in-differences estimate of the wage effect in column (1'), for living wage laws overall, is 2.62 , which falls short of statistical significance at conventional levels. Recall that this estimate gives the average effect of a living wage law relative to the experience in cities in which the living campaign failed or was derailed. In specifications 2 and 3, the estimates indicate stronger effects of both business assistance living wage laws and living wage laws accompanied by those in nearby cities. Again, the estimates go up by a factor somewhat below two, and for both types of living wage laws, the estimates indicate wage increases of about four percent in the bottom decile of the wage distribution. The effect is nearly statistically significant at the ten-percent level in the case of business assistance cities but falls farther short of statistical significance in the case of laws where nearby cities also have legislation. Also, as before, the estimated effects of other types of living wage laws (without business assistance provisions, or geographically isolated), are insignificantly different from zero. The results are similar but the point estimates a bit smaller in columns (2) and (2') where we restrict our attention only to the cities with derailed campaigns. Interestingly, the standard errors are generally a bit smaller, despite using a more restricted control group.

The employment effects are similar in some respects. In columns (3) and (3'), when we look at the effects of both failed and derailed campaigns, the differential effect in cities that pass living wage laws is negative and statistically significant at the five-percent level, with the representative living wage law reducing employment by 3.6 percentage points. The estimates are stronger for business assistance living wage laws, and living wage laws accompanied by laws in nearby cities. In columns (4) and (4'), when attention is limited to just those cities with derailed campaigns, the differential effect for cities passing laws becomes smaller, with the representative living wage law reducing employment by 1.7 percentage points. Even for business assistance laws and legislation accompanied by laws in nearby cities, the differential effect is no longer statistically significant. This is largely due to the now negative (although non-significant) employment estimate in the first row for each specification corresponding to failed or derailed campaigns, and the considerably larger standard errors of those estimates using the narrower control group when we look at employment. 
Together, the evidence in columns (1') (2'), (3'), and (4') of Table 5 establishes what we view as our best evidence on the effects of living wage laws. The estimates in columns (1') and (3') tell a clear story. What is interesting about these estimates, which are identified relative to the changes that occurred in cities with failed or derailed living wage campaigns in the period when living wages would probably have been implemented in these latter cities had the campaigns been successful, is that they are if anything stronger than the estimates in Table 4. Further information along these lines is provided in the estimates reported in columns (1) and (3) of Table 5. These estimates suggest that the "effects" corresponding to failed or derailed living wage campaigns are, if anything, the opposite sign of the estimated effects of successful campaigns (i.e., negative wage effects and positive employment effects), although these estimates are insignificant.

The estimates in columns (2') and (4') are not as clear. We use the control group of cities where campaigns ended due to outside legislative or judicial action, which could be preferable, and the estimates do suggest a differential effect of the laws themselves compared with the control group, but the effects are weaker and not statistically significant. We cannot be certain, but this may reflect the five cities with derailed campaigns not providing enough data to draw a reliable conclusion. Finally, we remind the reader that the derailed campaigns do not unambiguously represent a better control group, because in only two of the five cities in this group was a living wage law passed before it was nullified.

In all cases, though, the estimated effects of unsuccessful living wage campaigns—given in the first row for each specification — never give any indication that these have any effects. In every case the estimate is smaller than the standard error, and in almost every case (the one exception is in column (4)) the estimates are the opposite sign to the estimated effects of successful living wage campaigns.

Taken together, the evidence suggests that it is the actual living wage laws, rather than the effects of living campaigns per se, that generate the estimated wage and employment effects that we find. That is, for a living wage movement to ultimately have a detectable effect on the wages or employment of lowwage or low-skill workers, it appears that it must culminate in legislation that is passed by the city and subsequently enforced. This evidence on the effects of enacted living wage laws relative to living wage 
campaigns suggests that it is not necessarily anything about living wage campaigns themselves that explains the large living wage impacts that we find, whether considering living wage laws in general, or the stronger effects we find for particular types of living wage laws. Rather, the effects appear to be driven by the wage floors and other provisions established by the living wage legislation that is enacted.

\section{Conclusions}

This paper exploits the experiences of cities with living wage campaigns that were ultimately unsuccessful to construct more compelling counterfactuals with which to estimate the effects of living wage laws. Some campaigns were unsuccessful because they were derailed due to state legislation or a court ruling. Others failed due a negative city council vote or a mayoral veto.

Specifically, the cities with unsuccessful living wage campaigns offer three advantages relative to earlier research. First, these cities arguably provide a better control group for comparison with the cities that passed living wage laws, as underlying changes in low-wage labor markets that may have been associated with living wage laws are more likely to have been similar in cities where living wage campaigns arose. Second, the cities with failed or derailed living wage campaigns allow us to estimate the effects of living wages more directly, by netting out the possible consequences of changes that accompany living wage campaigns, stemming from influences such as increased organizing among lowwage workers and increased public focus on their conditions and wages. With respect to both of these points, it might be expected that smaller living wage effects on wages and employment would result, compared with evidence based on comparisons with the broader set of cities that simply did not pass living wage laws—irrespective of whether a living wage campaign occurred. And third, our approach yields estimates of the effects of living wage campaigns themselves.

The results confirm the findings of positive wage effects and negative employment effects of enacted living wages on low-wage, low-skill workers. In fact, the findings are generally very similar to the previous results using a broader control group. The evidence also suggests that there is no detectable impact of living wage campaigns themselves, apart from the legislation that results. 
The robustness of the findings to narrowing the control group to cities with failed or derailed living wage campaigns suggests that the more basic panel data research design recovers unbiased estimates of the effects of living wage laws. Recall that this seemed a particularly important question to explore in the context of living wages because others have argued that the rather large effects we have found may be partly attributable to the effects of campaigns; that is, some skepticism has been directed toward our estimates precisely on the basis of the type of argument we address in this paper. More generally, in empirical analyses of this type that identify effects of policies from variation in policies over geographical areas and time, there is a legitimate concern that the policy variation may be endogenous, so that apparent effects of the policy are in fact a reflection of changes that drove the policy variation, rather than the other way around. The robustness of the estimates of living wage effects that we find therefore suggests a couple of conclusions. First, the wage and employment effects we find are in fact not attributable to the effects of living wage campaigns, but rather to the effects of the laws themselves; in that sense, our analysis solidifies the existing findings. Nor are they likely attributable to endogeneity of the locations where living wage laws arise. Finally, in this particular context the reason we do not find a different answer using the control group of failed and derailed campaigns is that the usual toolkit applied in panel data contexts, including fixed city and year effects, and city-specific time trends, turns out to do enough to capture the important differences between the treatment and control group. ${ }^{24}$

The findings have some implications for the evolving literature on living wages. First, as just noted, the relatively large effects of living wages that we have found receive further confirmation from this paper, suggesting that the question of why these effects appear larger than expected based on factors such as contractor coverage continues to merit investigation. In our view, one promising avenue of research that may prove informative is the development of research using firm-level data to gain better

\footnotetext{
${ }^{24}$ To confirm this, we estimated the specifications in Table 3, with the alternative control groups, leaving out the time trends, the city dummy variables, and then both. This often led to much greater sensitivity of the results to using the narrower control group. For example, focusing on the wage effects reported in column (1) of Table 3, the range of estimates based on the three control groups is 0.17 . If we omit the trend terms, the range grows to 2.93 , and if we omit the trends and city dummy variables, it grows to 6.69. For the employment effects in column (4) of Table 3 , the range of estimates is 0.29 . Without the trends this grows to 1.07 , and without the trends and city dummy variables to 5.37 .
} 
insight into the behavioral responses of firms to legislation (Brenner [16] and Fairris [17]). As for living wage movements, the evidence in this paper does not point to discernable impacts of living wage campaigns per se. At the same time, our approach to this question represents a first stab; a particular limitation arises from the difficulty of trying to "date" when the effects of derailed living wage campaigns would have arisen. In addition, more study of the development and dynamics of living wage campaigns—including why they arise and why they succeed or fail—would likely prove insightful, and might point to some sources of variation in whether or not living wage campaigns have more persistent effects, as well as possible differences among living wage campaigns that result in different types of living wage laws. 


\section{References}

[1] D. Neumark, S. Adams, Detecting Effects of Living Wage Laws, Industrial Relations 42 (2003) 531-564.

[2] D. Neumark, S. Adams, Do Living Wage Ordinances Reduce Urban Poverty?, Journal of Human Resources 38 (2003) 490-521.

[3] S. Adams, D. Neumark, Living Wage Effects: New and Improved Evidence, Economic Development Quarterly 19 (2005) 80-102.

[4] S. Luce, Fighting for a Living Wage: The Politics of Implementation, Cornell University Press, Ithaca, NY, 2004.

[5] C. Zabin, I. Martin, Living Wage Campaigns in the Economic Policy Arena: Four Case Studies from California, Center for Labor Research and Education, Institute of Industrial Relations, University of California, Berkeley, unpublished manuscript 1999.

[6] J.P. Smith, F. Welch, Affirmative Action and Labor Markets, Journal of Labor Economics 2 (1984) 269-301.

[7] T. Thomason, T.P. Schmidle, J.F. Burton, Jr., Workers' Compensation: Benefits, Costs, and Safety under Alternative Insurance Arrangements, Kalamazoo, MI: The W.E. Upjohn Institute for Employment Research, Kalamazoo, MI 2001.

[8] R.V. Burkhauser, K.A. Couch, D.C. Wittenburg, A Reassessment of the New Economics of the Minimum Wage Literature with Monthly Data from the Current Population Survey, Journal of Labor Economics 18 (2000) 653-680.

[9] M.P. Bitler, J.B. Gelbach, H.W. Hoynes, Some Evidence on Race, Welfare Reform, and Household Income, American Economic Review Papers and Proceedings 93 (2003) 293-298.

[10] J. Gruber, The Incidence of Mandated Maternity Benefits, American Economic Review 84 (1994) 622-641.

[11] J. DiNardo, D.S. Lee, The Impact of Unionization on Establishment Closure: A Regression Discontinuity Analysis of Representation Elections, Working Paper No. 8993, National Bureau of Economic Research, Cambridge, MA 2002.

[12] S. Lundberg, D. Jacoby, E. Rose, E. Steinman, The Economic Effects of Living Wage Ordinances, Unpublished manuscript, University of Washington.

[13] S. Adams, D. Neumark, When Do Living Wages Bite?, Industrial Relations 44 (2005) 164-192.

[14] U.S. Bureau of Labor Statistics, BLS Handbook of Methods, Washington, DC, http://www.bls.gov/opub/hom/homtoc.htm 2004.

[15] U.S. Bureau of the Census, CPS Technical Paper 63RV: Design and Methodology, Washington, DC, http://www.census.gov/prod/2002pubs/tp63rv.pdf 2002.

[16] M.D. Brenner, The Economic Impact of the Boston Living Wage Ordinance, Industrial Relations 
44 (2005) 164-192.

[17] D. Fairris, The Impact of Living Wages on Employers: A Control Group Analysis of the Los Angeles Ordinance, Industrial Relations 44 (2005) 59-83.

[18] R. H. Sander, S. Lokey, The Los Angeles Living Wage in Operation: A Preliminary Evaluation, California Labor \& Employment Quarterly 12 (1998) 5-7.

[19] M. Bertrand, E. Duflo, S. Mullainathan, How Much Should We Trust Differences-in-differences Estimates, Working Paper No. 8841, National Bureau of Economic Research, Cambridge, MA 2002. 
Table 1: Successful Living Wage Campaigns

\begin{tabular}{|c|c|c|c|c|}
\hline City & $\begin{array}{c}\text { Initial month that law } \\
\text { was enacted }\end{array}$ & $\begin{array}{l}\text { Living wage requirement } \\
\text { as of December } 2002\end{array}$ & Coverage & $\begin{array}{c}\text { Nearby city has a law } \\
\text { (year) }\end{array}$ \\
\hline Ann Arbor & April 2001 & 8.70 & $\mathrm{~B}, \mathrm{C}$ & Yes (1998) \\
\hline Baltimore & July 1995 & 8.20 & $\mathrm{C}$ & No \\
\hline Bellingham & December 2002 & 10.00 & $\mathrm{C}$ & No \\
\hline Boston & October 1998 & 10.25 & $\mathrm{C}$ & Yes (1999) \\
\hline Burlington & December 2001 & 9.90 & $\mathrm{C}, \mathrm{M}$ & No \\
\hline Charlottesville & December 2001 & 8.00 & $\mathrm{C}$ & No \\
\hline Chicago & August 1998 & 9.05 & $\mathrm{C}$ & No \\
\hline Cleveland & January 2001 & 9.20 & $\mathrm{~B}, \mathrm{C}, \mathrm{M}$ & No \\
\hline Dayton & April 1998 & 7.00 & $\mathrm{M}$ & No \\
\hline Denver & March 2000 & 8.70 & $\mathrm{C}$ & No \\
\hline Detroit & December 1998 & 9.05 & $\mathrm{~B}, \mathrm{C}$ & Yes (1999) \\
\hline Duluth & August 1997 & 6.50 & $\mathrm{~B}$ & No \\
\hline Durham & February 1998 & 8.45 & $\mathrm{C}, \mathrm{M}$ & No \\
\hline Gainesville & October 2001 & 8.56 & $\mathrm{M}$ & No \\
\hline Hartford & October 1999 & 9.96 & $\mathrm{~B}, \mathrm{C}$ & Yes (1997) \\
\hline Jersey City & July 1996 & 7.50 & $\mathrm{C}$ & No \\
\hline Los Angeles & April 1997 & 8.17 & $\mathrm{~B}, \mathrm{C}$ & Yes (1996) \\
\hline Madison & April 1999 & 9.05 & $\mathrm{~B}, \mathrm{M}$ & No \\
\hline Milwaukee & December 1995 & 7.22 & $\mathrm{C}$ & No \\
\hline Minneapolis & April 1997 & 9.05 & B & Yes (1997) \\
\hline New Haven & May 1997 & 10.86 & $\mathrm{C}$ & Yes (1999) \\
\hline Oakland & April 1998 & 8.72 & $\mathrm{~B}, \mathrm{C}$ & Yes (1998) \\
\hline Portland & July 1996 & 8.00 & $\mathrm{C}$ & No \\
\hline Rochester & January 2001 & 8.76 & $\mathrm{~B}, \mathrm{C}, \mathrm{M}$ & No \\
\hline San Antonio & August 1998 & 9.27 & $\mathrm{~B}$ & No \\
\hline San Francisco & September 2000 & 10.00 & $\mathrm{C}$ & Yes (1998) \\
\hline San Jose & December 1998 & 10.36 & $\mathrm{~B}, \mathrm{C}, \mathrm{M}$ & Yes (1998) \\
\hline Toledo & June 2000 & 9.96 & $\mathrm{~B}, \mathrm{C}, \mathrm{M}$ & No \\
\hline Tucson & October 1999 & 8.57 & $\mathrm{C}$ & No \\
\hline
\end{tabular}

This table was compiled using information from the Employment Policies Institute

(http://www.epionline.org/lw_proposal_map.cfm and http://www.epf.org/factsheets/adopted.asp). It includes the cities that are large enough to be included in the empirical analysis, specifically those for which there are at least 25 observations for some months in the sample period. There are also many cases of smaller cities within metropolitan areas encompassing these larger cities that have living wages, often quite similar to those in the larger city. The date the living wage was enacted is identified by the first complete month the ordinance was effective, when that information is available. Otherwise, the date at which the ordinance was passed is assumed to be the effective date. In the "coverage" column, C indicates the contractors are covered, B indicates that business assistance recipients are covered, and $\mathrm{M}$ indicates that municipal employees are covered. Some cities impose a higher living wage if health insurance is not provided. The lower wage floor is reported in the table and used in the analysis; in previous work, we verified that results are very similar using the higher wage floor (Neumark and Adams [2]). 
Table 2: Failed and derailed living wage campaigns

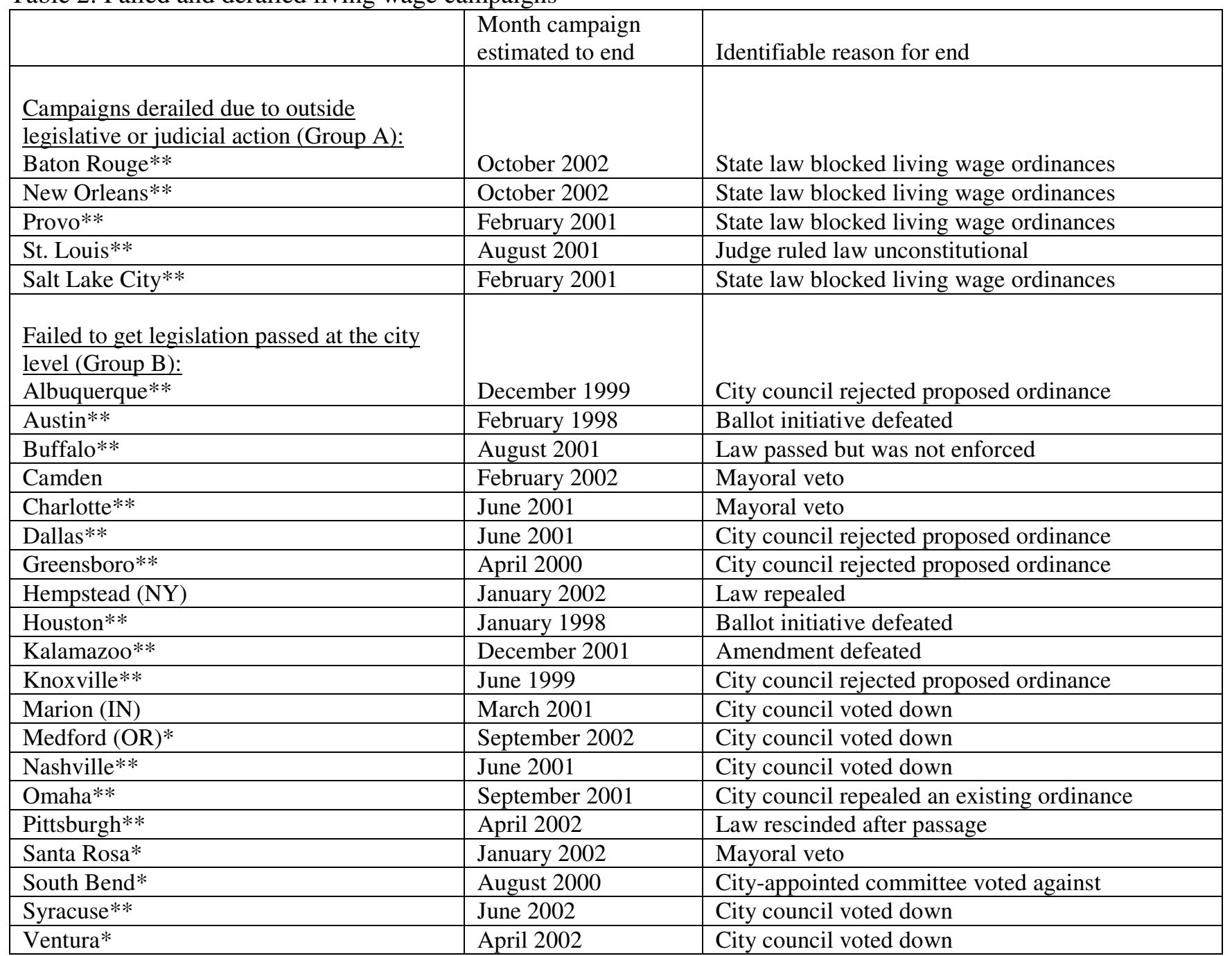

This table was compiled using information from http://www.epionline.org/livingwage/index.cfm. The dates that the campaigns ended are estimates. For many cities, campaign activity may have resumed. For these cities, we restrict attention to when the first campaign ended. Not all of the cities shown in the table are large enough to be included in the analysis. (See notes to Table 1.) A city with one asterisk (*) made the sample cut for the employment analysis only. A city with two asterisks $(* *)$ made the cut for both the wage and employment analyses. A city with no asterisk did not make the sample. 
Table 3: Effects of the Logs of Living Wages on Workers in the Bottom Decile of the Wage or Skill Distribution, 19962002

\begin{tabular}{|c|c|c|c|c|c|c|}
\hline & \multicolumn{3}{|c|}{ Log wage } & \multicolumn{3}{|c|}{ Employment } \\
\hline & (1) & (2) & (3) & (4) & $(5)$ & (6) \\
\hline$\frac{\text { All other urban areas as controls: }}{\text { Log living wage } 12 \text { months ago }}$ & $\begin{array}{c}3.95 \\
(2.97)\end{array}$ & $\ldots$ & $\ldots$ & $\begin{array}{l}-5.25 \\
(1.95)\end{array}$ & $\ldots$ & $\ldots$ \\
\hline$\times$ business assistance coverage & $\ldots$ & $\begin{array}{c}6.54 \\
(3.83)\end{array}$ & $\cdots$ & $\ldots$ & $\begin{array}{l}-7.50 \\
(1.79)\end{array}$ & $\cdots$ \\
\hline$\times$ contractors only & $\ldots$ & $\begin{array}{l}-0.50 \\
(3.72) \\
\end{array}$ & $\cdots$ & $\ldots$ & $\begin{array}{l}-2.88 \\
(3.43) \\
\end{array}$ & $\cdots$ \\
\hline$\times$ laws in nearby cities & $\ldots$ & $\ldots$ & $\begin{array}{c}9.14 \\
(3.96)\end{array}$ & $\ldots$ & $\ldots$ & $\begin{array}{l}-9.85 \\
(2.20)\end{array}$ \\
\hline$\times$ no laws in nearby cities & $\cdots$ & $\ldots$ & $\begin{array}{l}-2.15 \\
(3.40)\end{array}$ & $\cdots$ & $\cdots$ & $\begin{array}{l}-1.65 \\
(2.30)\end{array}$ \\
\hline Sample size & \multicolumn{3}{|c|}{48,709} & \multicolumn{3}{|c|}{121,137} \\
\hline $\begin{array}{l}\text { All cities with derailed }(\mathrm{A}) \text { or failed }(\mathrm{B}) \\
\text { campaigns as controls: } \\
\text { Log living wage } 12 \text { months ago }\end{array}$ & $\begin{array}{c}3.78 \\
(3.02)\end{array}$ & $\ldots$ & $\ldots$ & $\begin{array}{l}-5.36 \\
(1.93)\end{array}$ & ... & $\ldots$ \\
\hline$\times$ business assistance coverage & $\ldots$ & $\begin{array}{c}5.91 \\
(3.90)\end{array}$ & $\ldots$ & $\ldots$ & $\begin{array}{l}-7.28 \\
(1.81)\end{array}$ & $\ldots$ \\
\hline$\times$ contractors only & $\ldots$ & $\begin{array}{c}-0.20 \\
(3.88) \\
\end{array}$ & $\ldots$ & $\ldots$ & $\begin{array}{l}-3.32 \\
(3.48) \\
\end{array}$ & $\cdots$ \\
\hline$\times$ laws in nearby cities & $\ldots$ & $\ldots$ & $\begin{array}{c}8.09 \\
(4.07)\end{array}$ & $\ldots$ & $\ldots$ & $\begin{array}{l}-9.81 \\
(2.49)\end{array}$ \\
\hline$\times$ no laws in nearby cities & $\cdots$ & $\cdots$ & $\begin{array}{l}-2.22 \\
(3.84)\end{array}$ & $\cdots$ & $\cdots$ & $\begin{array}{l}-2.05 \\
(2.37)\end{array}$ \\
\hline Sample size & \multicolumn{3}{|c|}{22,848} & \multicolumn{3}{|c|}{49,688} \\
\hline $\begin{array}{l}\text { All cities with derailed (A) campaigns } \\
\text { as controls: } \\
\text { Log living wage } 12 \text { months ago }\end{array}$ & $\begin{array}{c}3.92 \\
(3.01)\end{array}$ & .. & $\ldots$ & $\begin{array}{l}-5.54 \\
(1.84)\end{array}$ & ... & $\ldots$ \\
\hline$\times$ business assistance coverage & $\ldots$ & $\begin{array}{c}5.74 \\
(3.96)\end{array}$ & $\ldots$ & $\ldots$ & $\begin{array}{l}-7.52 \\
(1.89)\end{array}$ & $\ldots$ \\
\hline$\times$ contractors only & $\cdots$ & $\begin{array}{c}0.58 \\
(3.95) \\
\end{array}$ & $\ldots$ & $\ldots$ & $\begin{array}{l}-3.92 \\
(3.39) \\
\end{array}$ & $\cdots$ \\
\hline$\times$ laws in nearby cities & $\ldots$ & $\ldots$ & $\begin{array}{c}8.24 \\
(4.22)\end{array}$ & .. & $\ldots$ & $\begin{array}{l}-9.36 \\
(2.53)\end{array}$ \\
\hline$\times$ no laws in nearby cities & $\ldots$ & $\ldots$ & $\begin{array}{l}-1.57 \\
(4.12)\end{array}$ & $\cdots$ & $\ldots$ & $\begin{array}{l}-2.46 \\
(2.30)\end{array}$ \\
\hline Sample size & \multicolumn{3}{|c|}{17,623} & \multicolumn{3}{|c|}{37,845} \\
\hline
\end{tabular}

Reported are the estimated effects of the living wage on the log wage (employment) of individuals in the bottom decile of the wage (predicted wage) distribution in the MSA-month cell. Estimates of the effects on employment are from linear probability models. All estimates are multiplied by 100. Observations for which allocated information is required to construct the dependent variable in the CPS are dropped. The estimations include controls for year, month, MSA, education, age, marital status, race, gender, and the minimum wage at the same lag as the living wage variable. The living wage and minimum wage are measured in logs. Reported standard errors (in parentheses) are robust to non-independence (and heteroscedasticity) within city cells, following the suggestions in Bertrand et al. [19]. See Table 2 for a list of those cities with derailed campaigns (group A) and failed campaigns (group B). 
Table 4: Effects of the Existence of a Law on Workers in the Bottom Decile of the Wage or Skill Distribution, all control groups, 1996-2002

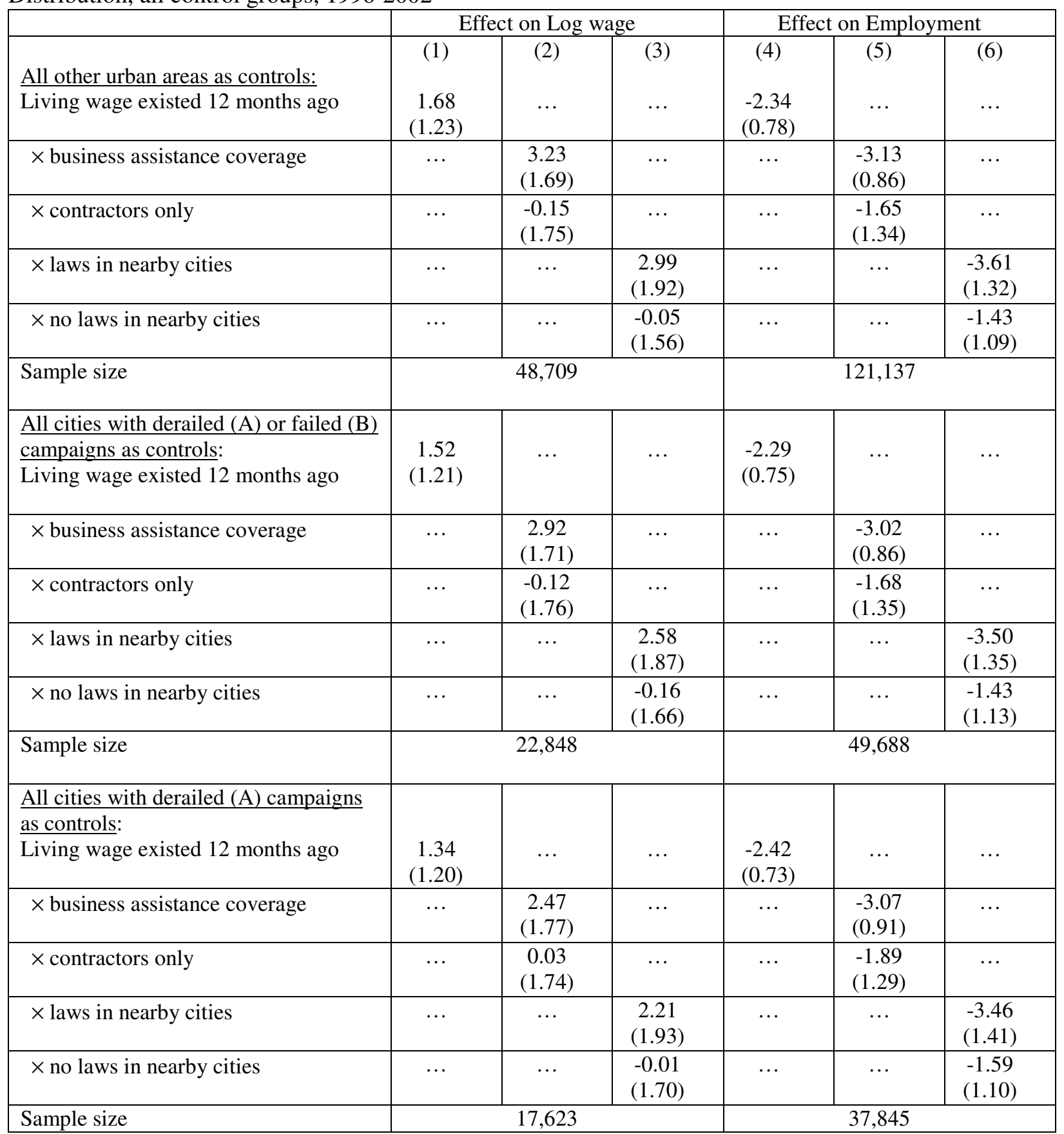

See Table 2 for a list of those cities with derailed campaigns (group A) and failed campaigns (group B). See Table 3 for notes on the specification and estimation. 
Table 5: Effects of Living Wage Movements on Workers in the Bottom Decile of the Wage or Skill Distribution, 1996-2002

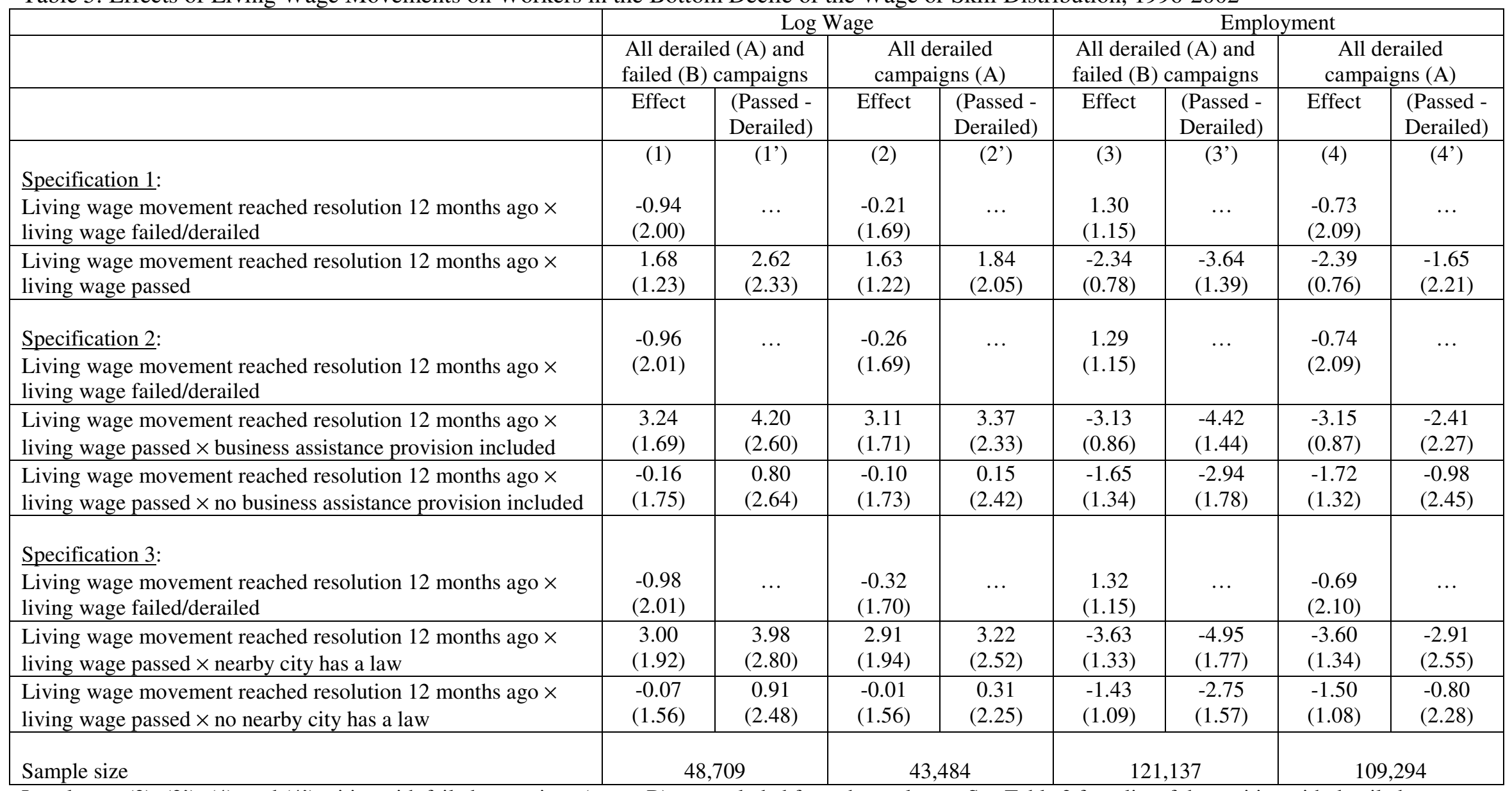

In columns (2), (2'), (4), and (4'), cities with failed campaigns (group B) are excluded from the analyses. See Table 2 for a list of those cities with derailed

campaigns (group A) and failed campaigns (group B). See Table 3 for notes on the specification and estimation. 